\title{
Migration in the Southern Border of Mexico from the Ethics of Liberation - An Analysis
}

\author{
Arturo G. Rillo ${ }^{\star}$ and Beatriz E. Martínez-Carrillo \\ ${ }^{1}$ Faculty of Medicine, Autonomous University of the State of Mexico, Mexico.
}

Authors' contributions

This work was carried out in collaboration between both authors. They designed the study, performed the statistical analysis, wrote the protocol and wrote the manuscript. Both authors read and approved the final manuscript.

Article Information

DOI: $10.9734 /$ ARJASS/2017/33829

Editor(s):

(1) Ana Sofia Pedrosa Gomes dos Santos, Department of Education, Social Sciences, and Humanities, University of Lisbon,

Reviewers

(1) Zerrin Toprak, Karaman, Dokuz Eylül University, Turkey.

(2) Adetoro Rasheed Adenrele, Federal College of Education, Abeokuta, Nigeria.

(3) Mehmet Ali Eryurt, Hacettepe University, Ankara, Turkey.

(4) Tacel Ramberto Coutinho Leal, State University of Londrina (UEL), Brazil. (5) Alberto da Silva Moreira, Pontifical Catholic University of Goiás, Goiânia, Brazil.

Complete Peer review History: http://www.sciencedomain.org/review-history/19521

Original Research Article

Received $30^{\text {th }}$ April 2017

Accepted $10^{\text {th }}$ June 2017

Published $14^{\text {th }}$ June 2017

\begin{abstract}
Introduction: Mexico's southern border is the main gateway of Central American migrants bound for the United States, exposing themselves to risks that have created a humanitarian crisis.

Aims: To carry out an analysis of the ethical foundations related to the migratory movements of the southern border of Mexico.

Study Design: An observational, retrospective, cross-sectional, analytical and documentary study of mixed qualitative type was carried out using the hermeneutic-interpretative approach.

Methodology: The study was developed in two stages and four phases (analytical, comprehensive, reconstructive, critical). The documentary analysis was made using philosophical research techniques. The theoretical posture included the liberation ethics proposed by Enrique Dussel. The variables of the study were: border conceptualization, humanitarian crisis and praxical solidarity. Statistical information included the period 2002 to 2014 and was obtained from the migratory statistics bulletins and the Survey of Migration of the Southern Border of Mexico. The information was recorded on an ad hoc data collection sheet. All analyses were done in simple percentages.

Results: The results show a cyclical tendency in the return of migrants to their country of origin.
\end{abstract}


Those from Honduras report the highest perception of risk. Survival risks are the most common. Accidents and injuries decreased during the period 2011 to 2013 . In $2013,4.8 \%$ of migrants reported being extorted and $8.1 \%$ attacked. The conditions of the transmigrants were highlighted. From the standpoint of liberation ethics, solidarity is analyzed as the encounter with the constituent transmigrant of being-in-the-world that comes from the otherness in the recognition of oneself and the plurality of the other; where the horizon of meaning is delimited by friendship, love, care and hospitality.

Conclusion: The praxical solidarity represents a hermeneutic nucleus in the historical praxis of the exclusion, marginalization and segregation of the migrant.

Keywords: Ethics of liberation; human rights; migration; solidarity; southern border.

\section{INTRODUCTION}

The southern border of Mexico has an extension of $1149 \mathrm{~km}$, of which $193 \mathrm{~km}$ are border with Belize and $946 \mathrm{~km}$ with Guatemala. It is currently the main entry route for Central American migrants to the United States of America (USA); favoring that Mexico be shown as a country that is no longer an origin, destination and return of migratory flows, but has become a bridgecountry, reflecting different facets of international migration [1].

One of these facets is the transmigration, defined as the irregular migratory flow of traffic through a region going from an area of minor to another one of greater economic development. So it has social, economic, political, legal and cultural implications [2].

Undocumented migrants from Central America who enter the southern border and transit through Mexico into the USA are a highly vulnerable population at social risk of victimization. A humanitarian crisis has been generated by being unprotected against drug trafficking, violence linked to organized crime and trafficking in migrants [3]. This situation of vulnerability includes: Homicides, attack, kidnappings, disappearances, acts of sexual violence, human trafficking, migrant smuggling, discrimination and illegal detention without judicial protection [4].

The humanitarian crisis of Central American migrants to the USA traveling through Mexico has led to the emergence of specialized literature [5] and generated interest in sociology, anthropology, medicine and human rights. In order to try to understand it, maps of identified risk [6] have elaborated transmigratory routes and conditions of victimization [7]; as well as showing the border as a risk metaphor [8]. The Inter-American Commission on Human Rights (IACHR) has given meaning to the humanitarian crisis in the following terms: "The extreme vulnerability of migrants and others in the context of human mobility in Mexico is one of the main Humanitarian tragedies and massive violations of human rights in the region" [1].

Theoretically and empirically, the humanitarian problem is not only being shaped by the description and analysis of the political, anthropological and sociological dimensions of transmigration; but in relation to ethics, the analysis focuses on the violation of human rights. In this sense, the ethic of the transmigrant is yet to be written. Analytical approaches from liberal ethical positions, moral nihilism, political realism, or community ethics [9] have not deepened the search for answers to the following questions: how does a frontier in the globalized world become possible? [10] Is the denomination of undocumented migrant, an existential condition of being-in-the-world? [11] Is the vulnerability of the undocumented migrants the extension of the victimization process that suffers in their place of origin? [12].

When crossing the border, the transmigrant finds a world of risk, reinterpreting relationships with oneself and with others from symbolic reference of insecurity and vulnerability, making it easier to decode the adversities of reality and develop cognitive structures which encode reality in symbolic mediations [13]. The imaginative social probability of suffering a risk translates into acting images to respond to a worldview that is culturally opposed to the prevailing world view on the "other side" of the border.

The multiplicity of contradictions in the life of the transmigrants during his transit through Mexico reconfigures imagined social risk and vulnerability as "social schemes constructed to perceive as real the dangers, threats and insecurities that are considered latent" [14], so that the border is shown as a metaphor of risk in which realities are hidden that will give meaning 
to the ethos of the transmigrant [14]. In this sense, the following questions arise: does the Mexican corridor of international transmigration establishes migratory routes to the USA, involve a different connotation of the term as a "border"? Is the humanitarian crisis of the transmigrants in Mexico, is based on the analysis and perception of the risk of victimization? Does the empirical evidence supporting the humanitarian crisis of migrants in Mexico contain elements to delineate a migrant ethic?

The perception of risks referred to by the transmigrant helps to understand their vulnerability to the insecurity that prevails in Mexico and gives meaning to solidarity in terms of the actions that the subject performs to survive adversity. In this context, the study was carried out with the purpose of analyzing the ethical foundations related to the migratory movements in the southern border of Mexico.

\section{METHODOLOGY}

An observational, retrospective, cross-sectional, analytical and documentary study of mixed qualitative type was carried out [15] using the hermeneutic-interpretative approach and it was developed in two stages and four phases. (Fig. 1)
In the first stage the thematic field was delimited to the ethics of liberation to identify the relations that are established the transmigration in Mexico. It included two phases: the analytical phase and the comprehensive phase. In the analytical phase, the documentary analysis $[16,17]$ was carried out using techniques of philosophical investigation [18] of the texts of Enrique Dussel [19-22] in which the ethics of liberation are exposed. The thematic analysis were carried out based on the operational definition of the variables of the study: conceptualization of border, humanitarian crisis and praxical solidarity [23]. In the comprehensive phase the statistical information was recovered; for which the operationalization of variables in the following domains was carried out: magnitude of the transmigration; analysis and perception of risk; narratives of transmigrants (Fig. 1). The data were obtained from the statistical series of migration of the southern border prepared by the National Institute of Geography and Informatics (INEGI) and the National Institute of Migration (INM) through the Bulletin of Migratory Statistics from 2002 to 2014 [24] and of the Survey of Migration of the Southern Border during the period 2004 to 2014 [25]. The information was recorded on an ad hoc data collection sheet, and the database was built into the SPSS (15 version)

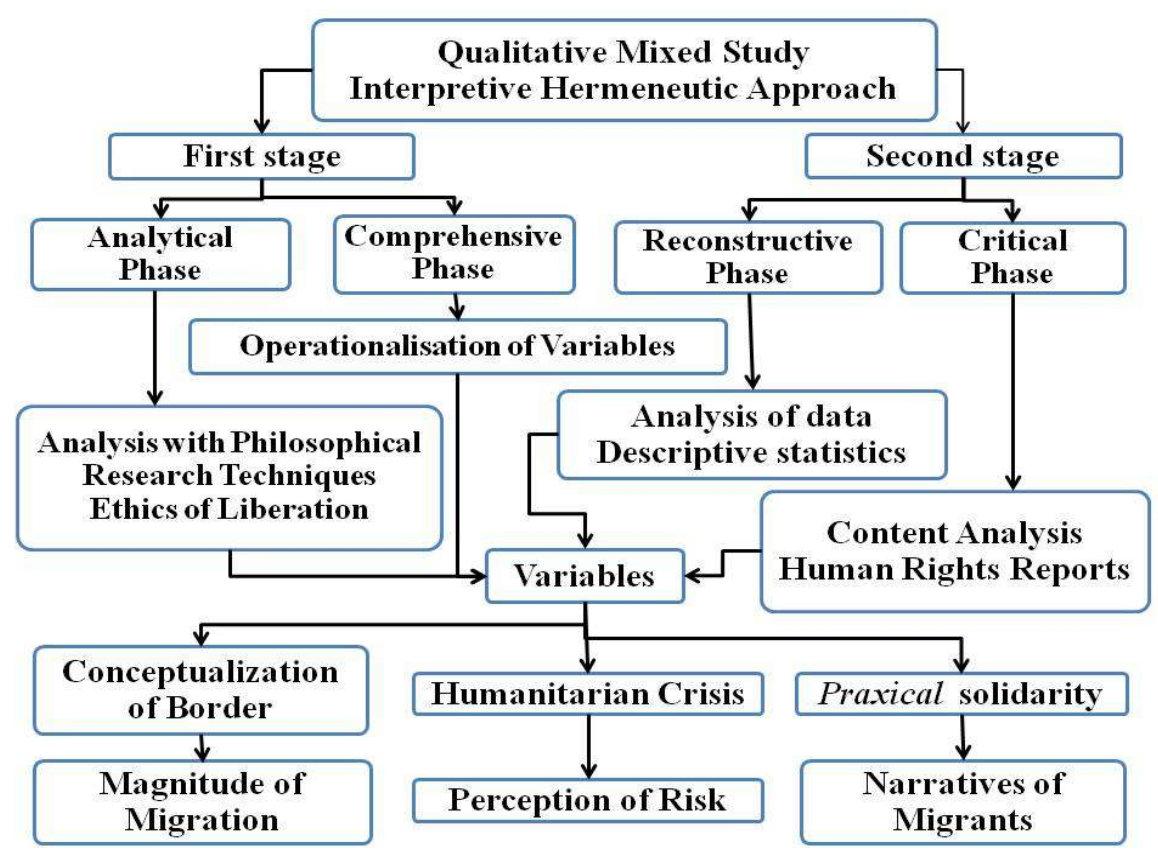

Fig. 1. Schematic representation of the study design 
In the second stage the variables and the different phases of the study were articulated, making possible the understanding of the relation between the ethics of liberation and transmigration. It included the reconstructive and critical phases. In the reconstructive phase, the data were analyzed using descriptive statistics and expressed in percentage values. The annual growth was calculated as the difference expressed as a percentage of the number of returns of migrants to their country of origin in the current year and the previous year. The critical phase was calculated using, the content analysis of the reports published by Amnesty International [7], the IACHR [1], the National Commission for Human Rights (CNDH) of Mexico [26,27], the Institute for Security and Democracy [28], the Chamber of Deputies of Mexico [29], the International Organization of Migration [30] and the United Nations Development Program [31]. The content analysis was performed using the method described by Elo and Kyngäs [32]. In the categorization of thematic contents, the method described by Rodríguez-Sabiote et al. [33] was used; and the quality of the research process was guaranteed by meeting the truth criteria of the hermeneutic-interpretative paradigm $[34,35]$.

Finally, the qualitative and quantitative results were integrated to be interpreted from the contextual framework of the liberation ethics, making it possible to expose the scales of praxical solidarity in the orientation of new areas of hermeneutic research.

\section{RESULTS AND DISCUSSION}

The migratory phenomenon that develops in the southern border shows a theoretical-conceptual, methodological and empirical complexity that is presented when analyzing the historical evolution of the number of people that returned to Guatemala, Honduras and El Salvador in the period from 2001 to 2014. Fig. 2. shows three trends that distinguish specific periods of irregular migratory movements. In the period 2002 to 2005, the trend of people returned by Mexican authorities to their country of origin was increasing, representing an increase in the period of $64.29 \%$. In 2006 , the downward trend began and ended in 2011, with a decrease of $67.33 \%$. However, the number of returns increased by $42.71 \%$ between 2012 and 2014 .

These results are consistent with MartínezVelasco's [36] report that attributed the destruction of railroad communication routes by Hurricane Stan in 2006 and the USA economic crisis in 2009 as causes of this decline. This does not exclude that violence, insecurity, extreme poverty, lack of opportunity for development and social welfare, inequality and economic inequality, political and ethnic conflicts that remain presently among the causes of the movement of undocumented migrants in Mexico [30].

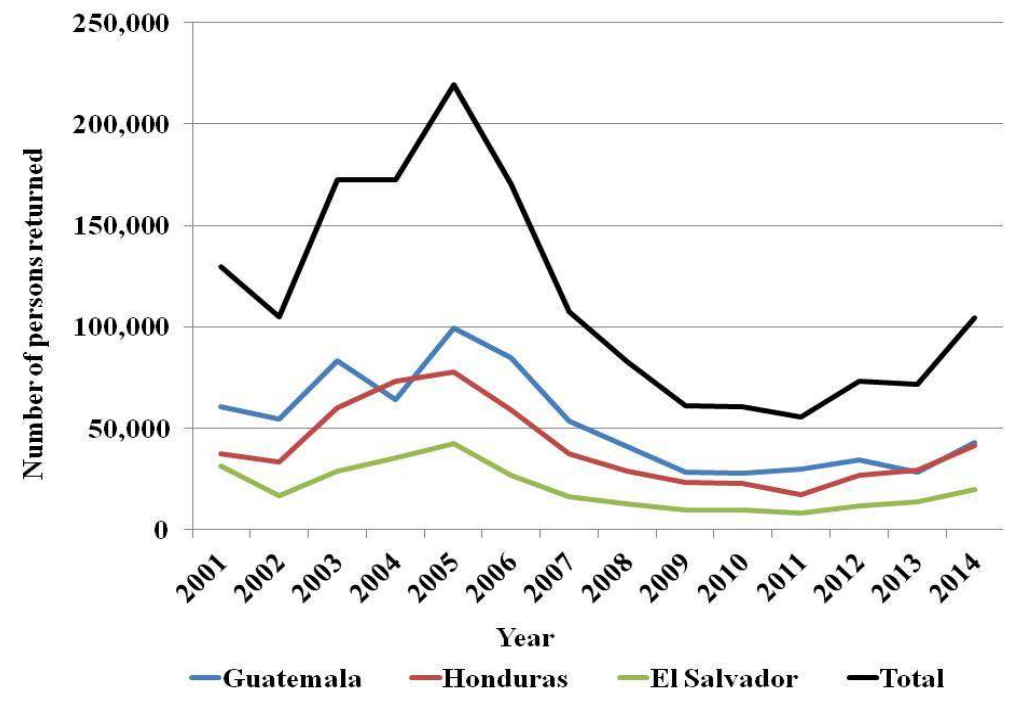

Fig. 2. Distribution of migrants returned to their country of origin by Mexican authorities in the period 2001 to 2014

Source: Prepared by the authors with data from the Migration Statistics Bulletin [24] and from the Southern EMIF from 2009 to 2013 [25] 
Irregular decreased migration may also be associated with: greater efficiency of migration control mechanisms, improved living conditions that lead to the displacement of migrants from their country of origin, increased risks to life faced by migrants in their transit through Mexico which translate in the increase of the vulnerability of the migrant and their victimization $[6,37]$.

The cyclical return of people to their country of origin by the Mexican authorities is interpreted through different theoretical, descriptive or holistic positions, ecological-cultural or historicalcritical. Fábregas-Puig and González-Ponciano [5] mention that the studies pointed to the analysis of the migration dynamics of the southern border using theoretical perspectives related to the historical construction of territoriality that includes concepts of space and region, and the development of anthropological studies to explain the colonization of the southern border, the increase of migratory flows, violence against the migrant and the violation of their human rights.

The historical-anthropological analysis carried out by Fábregas-Puig and González-Ponciano [5], exposes the formation of the southern border of Mexico as a space of economic, cultural and political convergence, and recovers the thesis: "all Mexico is a border". Extending the connotation and the implications of this thesis to the original structures of victimization enunciated in the ethics of liberation $[19,20]$ which shows a horizon of understanding of the migratory phenomenon in its historical evolution as a praxical representation of human action.

The ethics of liberation presupposes the possibility of analyzing transmigration in Mexico from the point of poverty, placing it in the realm of material ethics and the philosophy of praxis, through the principles of critical, material, formal, feasibility and liberation; which are translated in terms of the exhaustive search of the good historical-cultural life for himself and for others, implying a concept of the term "frontier" that transcends the idea of a line that delimits geopolitical areas.

\subsection{Conceptualization of the Southern Border of Mexico}

The term "border" is defined as the geographical line that divides a socio-political region from the other by which a migrant classifier system is established in documented (legal) and undocumented (illegal) ways [38]. The analysis of migratory flows has gradually led to questioning the term "frontier" as a dividing line between nation states, differentiating concepts of border, frontier and ethnic border [39]; approaching anthropological reconstructions such as border-periphery, border-center and icon border [40].

For the ethics of liberation, the frontier as a geopolitical line separates, marginalizes and victimizes the migrant. So, the frontier it is a social space where the dialectic of the colonization process is expressed in terms of continuities and discontinuities of economy, environment, culture, ethnic and politics. Considering the critical moral principle of liberation ethics, the analysis of the southern border is aimed at "seeking the causes of victimization of the dominated and projecting future positive alternatives to transform reality" [19].

In this context, the materiality of the world is expressed in the reproduction and development of the life of the Central American migrant and determines the universal truth content of the human act expressed in the ethical norm that governs the act of the transmigrant [19] and It contributes to the construction of the imagined social of transmigration as a community intersubjective and historical horizon from which "the reproduction and development of human life according to its basic needs, articulated to economic, cultural, political, religious and ethical demands" [20].

From the traditional interpretation of the term frontier, migration, expressed through returns to the country of origin, is declining. Interpreting the same data from the ethics of liberation, is a cyclical phenomenon that presents three phases of growth: Construction, deconstruction and reconstruction. For example, it has been recognized that the main flow of transmigrants comes from Guatemala, followed by Honduras and EI Salvador; but when analyzing the annual percentage change of people who returned to their country of origin between 2002 and 2014, differences between trends are identified according to the growth periods.

Table 1 show that the tendency of increase in the number of people from their country of origin between 2002 and 2005 is positive and corresponds to the first period of growth (construction of migratory flows in the $21 \mathrm{st}$ 
century). The greatest variation occurred in 2003 at the expense of people from Honduras and El Salvador; until 2005 when it recovers again the return of people to Guatemala.

The dialectic of marginality that underlies each of these periods shows the transition from the concept of border-periphery to that of bordercenter. In the first period, the levels of marginality in the border-periphery are centered on the patterns of social reproduction of the hegemonic material living conditions of the socio-territorial system that victimizes the migrant through criminalization by declaring it illegal in the territory crossing the border. In the third period, migratory flows increase in a heterogeneous way, making the border-center the area from which the victimization of the transmigrants is propitiated according to the predominant sociodemographic profile [40].

The transmigrant population destined to the USA during the period 2009 to 2012 is characterized mainly by being male population. The female population represents between $12.15 \%$ and $13.78 \%$ (Table 2). This proportion does not justify the trend of feminization of migration reported in other studies; so it may be the ideological burden of women's vulnerability to adverse conditions reported by the $\mathrm{CNDH}$ and the IACHR; in addition to gender studies, female migration is highlighted as an act of liberation [41].

$60 \%$ of the transmigrants have an age between 20 and 29 years. Those who speak some indigenous language are increasing, but do not represent more than 6\%; and those who can't read or write fall below $5 \%$. (Table 2) These characteristics show that the transmigrant is found in the exteriority of the dominant sociocultural system in which poverty transcends misery to shape the existence of victims subsumed in unhappiness, pain, domination, marginalization and exclusion. A situation that is worsening in the era of migration to the extent that the neoliberal project of global globalization manages to stabilize the structural and systemic revolution subject to the international dynamics of capital [29].

Dussel indicates that exteriority is the space where the human being is incorporated as part of the environment of the self-referential system, that is, of the hegemonic social, economic and cultural system that reifies on processes of alienation. Alienation implies that the historical and ethical subject is denied by the system by placing it in the exteriority of the same by turning it into a simple work force that is replaced through the buy-sell in the market. In this sense, transmigrants who report having worked in their place of residence during the last 30 days prior to migration are increasing from $54.27 \%$ in 2009 to $63.14 \%$ in 2012 , implying that unemployed transmigrants in their country of residence are decreasing. The sectors were $80 \%$ of the migrants are working in their place of residence are: agriculture, manufacturing and construction. (Table 2)

Table 1. Annual percentage change of migrants that were returned to their country of origin by Mexican authorities during the period 2002 to 2014

\begin{tabular}{llllll}
\hline Trend of growth & Year & Guatemala & Honduras & El Salvador & Total \\
\hline $\mathbf{1}^{\text {st }}$ Growth period & 2002 & -9.84 & -11.18 & -46.60 & -19.15 \\
& 2003 & 53.01 & 79.77 & 72.47 & 64.65 \\
& 2004 & -23.04 & 21.84 & 21.71 & 0.08 \\
\multirow{4}{*}{$\mathbf{2}^{\text {nd }}$ Growth period } & 2005 & 54.41 & 6.41 & 19.88 & 27.05 \\
& 2006 & $-14,76$ & -24.08 & -36.31 & -22.22 \\
& 2007 & -36.69 & -36.72 & -45.33 & -37.10 \\
& 2008 & -23.38 & -22.37 & -20.61 & $-22,60$ \\
& 2009 & -31.36 & -20.02 & -26.36 & -26.62 \\
& 2010 & -0.98 & -0.62 & 1.85 & 0.40 \\
$3^{\text {rd }}$ Growth period & 2011 & 7.52 & -24.40 & -14.72 & -8.16 \\
& 2012 & 15.04 & 53.15 & 42.76 & 31.08 \\
& 2013 & -17.32 & 10.23 & 16.07 & -1.84 \\
& 2014 & 49.97 & 41,67 & 43.79 & 45.38 \\
\hline \multicolumn{2}{l}{ Source: Prepared by the authors with data from the Migration Statistics Bulletin from 2002 a 2009 [24] and the }
\end{tabular}


Table 2. Percentage distribution of socio-demographic characteristics of Central American migrants bound for the USA which the Mexican authorities returned to their countries of origin, 2009 to 2012

\begin{tabular}{llllll}
\hline \multicolumn{2}{c}{ Characteristic } & $\mathbf{2 0 0 9}$ & $\mathbf{2 0 1 0}$ & $\mathbf{2 0 1 1}$ & $\mathbf{2 0 1 2}$ \\
\hline Sex & Male & 82.22 & 87.85 & 87.83 & 87.56 \\
\multirow{4}{*}{ Age } & Female & 13.78 & 12.15 & 12.17 & 12.44 \\
& 15 a 19 years & 13.80 & 15.86 & 12.82 & 10.26 \\
& 20 a 29 years & 58.29 & 58.17 & 60.65 & 64.35 \\
& 30 a 39 years & 20.86 & 20.41 & 21.16 & 20.79 \\
& 40 a 49 years & 5.97 & 4.92 & 3.81 & 4.11 \\
50 years or more & 1.08 & 0.64 & 1.56 & 0.49 \\
Speak indigenous language & 4.77 & 3.64 & 5.47 & 5.96 \\
He does not know to read nor to write & 6.69 & 5.35 & 5.71 & 4.87 \\
Work in place of residence & 54.27 & 59.51 & 62.17 & 63.14 \\
Occupation sector $\quad$ Agriculture & 19.81 & 23.04 & 27.93 & 31.56 \\
& Manufacture & 8.74 & 6.32 & 5.33 & 4.10 \\
& Construction & 14.58 & 15.85 & 16.18 & 15.43 \\
& Commerce & 3.83 & 3.17 & 2.88 & 2.22 \\
& Transport & 1.91 & 4.09 & 2.24 & 1.52 \\
& Domestic services & 0.79 & 1.19 & 1.23 & 1.15 \\
& Miscellaneous services & 4.61 & 5.96 & 6.35 & 7.04 \\
\hline
\end{tabular}

Source: Prepared by the authors with data from the Southern EMIF from 2009 to 2012 [25]

This profile shows the liberating intention of migrants, as a denial of the alienation and victimization of the transmigrant. For Dussel, liberation is the affirmation of the dignity of the victim even though the system does not know and marginalize it, giving meaning to the social reconstruction of the meaning of the frontier as an icon. The frontier-icon acquires validity in the understanding of the liberating phenomenon of the migration when recovering the deterritorialization of the border where "the cultures and the identities are creatively reinvented as complex and multidimensional forms of reference" [40]. The border-limit is deconstructed in concrete structures of domination. These integrate a social praxis that dignifies the suffering and recognizes their capacity as a speaker. The speech of the migrant, when developing in the frontier-icon, exposes several crises that affect the flow of transmigrants between those that emphasize: territoriality, cultural identity and inequality.

\subsection{Humanitarian Crisis}

Assuming that "all Mexico is border" in terms of border-icon it has two implications. The first is to understand the limit-situations enunciated by Karl Jaspers [42] as those fundamental situations for the human existence that contribute the suffering, the pain and the cut death; leading to the emergence of chronic and multiple stress (Ulysses syndrome) or the development of resilient mechanisms. The second refers to becoming aware of the victimization of the other, as Rigoberta Menchú has reflected in narrating her life history [43] to unveil the conditions that are generated from the hegemonic and exclusive systems that enable the emergence of the Humanitarian crisis of the transmigrants in Mexico, a reality that is complex, infinite and changing.

The vulnerability of the Central American migrant in transit is generated in a reality that translates into the perception of risk as the social imaginary from which the victimization of the object is explored [14]; which leads to differences between migrants according to the country of origin. For example, $100 \%$ of Honduran migrants transiting from Mexico into the USA perceived some risk during the years 2011 and 2012, decreasing in 2013 to $71.4 \%$. In the case of migrants from Guatemala, perceptions of risk are diminishing, and in the case of migrants from El Salvador, the perception of risk is increasing. (Table 3).

The risk of survival is frequently reported by the transmigrants during the period 2011 to 2013, and includes having suffered intense heat during the crossing of Mexico, lack of food, lack of water, fatigue for the walk, and getting lost on the road. The trend is increasing, mainly at the expense of migrants from El Salvador. Accidents and injuries are in third place and have 
decreased, registering $4.8 \%$ among migrants who have suffered train crashes, road crashes, aggression of wild animals and suffocation in the vehicle in which they were transported.

On the other hand, the ideological reference of the southern border refers to the imaginaries of the social movements that were exposed at the beginning of the $21^{\text {st }}$ century with the appearance of the Zapatista movement in Chiapas [44], favoring the militarization of the region and with it, the consolidation of the indifference of the Mexican State and society to the problem of transmigration. This indifference made it possible for the "mafia" of local authorities and state police officers and organized crime to carry out actions that led to the renewal of the victimization of the migrant accompanied by corruption, impunity and violation of human rights [45].

In 2011, $8.12 \%$ of Central American migrants reported having been extorted by gangs or Mexican authorities, a figure that increased in $2012(11.39 \%)$ but decrease to $4.8 \%$ in 2013 . On the other hand, in $2012,8.8 \%$ of the population reported having being attacked and this reduced to $8.10 \%$ in 2013 .

These results show the complex and changing nature of the humanitarian crisis of transmigrants in Mexico, adding the epistemic nature of the crisis because there is no consensus on the magnitude of the problem that is being experienced, even though the CNDH [27] has pointed out the need to have complete data to implement public policies that would address the humanitarian crisis suffered by migrants in Mexico. In addition, the southern border is resized by the uncertainty faced by the migrant crossing the border in search of a good life with philosophical reflections opened to solidarity.

\subsection{Praxical Solidarity}

The humanitarian crisis in Mexico is characterized by the victimization of the migrant; scenario that claims to give the word recognizing its alterity: "I have my family [...] I made a promise to them that I have to fulfill it [...] I know it is a pretty way of suffering but when you get there everything is achieved and everything is better" [7], mentioned by a Salvadoran migrant interviewed by Amnesty International.

Dussel [19] points out the importance of the other speaking and expressing their worldview and with this, from the community of sufferers, when listening to the victim, reflect ethical and critical awareness of the historical effect produced by the hegemony of European and American culture in the world-system of excluding characteristics.

It is the ethical and critical conscience in "knowing how to listen to the interpellation of the other in his suffering corporeality" [19], which will promotes explicit thematic criticism, whether scientific or philosophical, to recover the original, existential, historical meaning, concrete and ethical experience of the USA with the victims of poverty suffering from domination, exclusion and marginalization; which implies that it is not enough to state statistically the magnitude of the flow of the transmigrants.

To listen to them is to go beyond the objectivity of the data. This is shown by the reports of national and international organizations [1,7,26-31]. By means of the analysis of these documents the following scales are identified that

Table 3. Percentage distribution of Central Americans that were returned by USA authorities, by country of origin, as risk in crossing Mexico, 2011 to 2013

\begin{tabular}{lllllllllllll}
\hline $\begin{array}{l}\text { Perception } \\
\text { of risk }\end{array}$ & \multicolumn{3}{c}{ Guatemala } & \multicolumn{3}{c}{ Honduras } & \multicolumn{3}{c}{ El Salvador } & \multicolumn{3}{c}{ Total } \\
\cline { 2 - 13 } & $\mathbf{2 0 1 1}$ & $\mathbf{2 0 1 2}$ & $\mathbf{2 0 1 3}$ & $\mathbf{2 0 1 1}$ & $\mathbf{2 0 1 2}$ & $\mathbf{2 0 1 3}$ & $\mathbf{2 0 1 1}$ & $\mathbf{2 0 1 2}$ & $\mathbf{2 0 1 3}$ & $\mathbf{2 0 1 1}$ & $\mathbf{2 0 1 2}$ & $\mathbf{2 0 1 3}$ \\
\hline Any & 63.8 & 69.8 & 78.9 & 1.0 & 0.1 & 28.6 & 48.8 & 51.2 & 70.8 & 40.11 & 41.28 & 40.67 \\
Total risk & 36.2 & 30.2 & 21.1 & 99.0 & 99.9 & 71.4 & 51.2 & 48.8 & 29.2 & 59.89 & 58.72 & 59.33 \\
Survival & 28.9 & 19.5 & 57.5 & 7,2 & 14.0 & 15.9 & 42.0 & 43.1 & 26.7 & 25.21 & 22.49 & 38.11 \\
Fears & 0.8 & 0.8 & 0.8 & 28.6 & 11.0 & 2.3 & 4.3 & 1.4 & 0.2 & 10.53 & 4.51 & 1.15 \\
Accidents & 0.8 & 2.4 & 1.3 & 41.8 & 28.0 & 12.9 & 1.4 & 0.9 & 0.6 & 14.02 & 11.10 & 4.80 \\
and injuries & & & & & & & & & & & & \\
Extortion & 1.6 & 3.0 & 2.1 & 21.2 & 27.7 & 14.4 & 2.9 & 1.6 & 0.6 & 8.12 & 11.39 & 5.65 \\
Attack & DNA & 3.9 & 2.0 & DNA & 19.3 & 22.1 & DNA & 1.5 & 0.9 & DNA & 8.81 & 8.10 \\
Others & 4.2 & 0.6 & 0.4 & 0.1 & 0.2 & 4.1 & 0.6 & 0.4 & 0.2 & 2.01 & 0.42 & 1.52 \\
\hline
\end{tabular}

Source: Prepared by the authors with data from the Southern EMIF from 2011 to 2013 [25] 
delimit thematic fields for an ethic of the transmigrant: The friendship, the love, the care and the hospitality; so that migration studies need to transcend socio-economic impact analysis and offer lines of cultural and existential reflection linked to the overcoming of poverty through the appropriation of resilient strategies that motivate the migrants in the pursuit of inclusive and sustainable development.

Teresa, a 25-year-old Salvadoran migrant, reveals dreams, longings, responsibilities and solidarity during an interview: "Arriaga decided to take the train. Many people said, "No, it's dangerous here" [...] however, my vision has always been my children, and I wanted to come up the train, so I felt like a princess" [7]. But what solidarity is being talked about? Solidarity that arises from boundary situations that requires closeness to the other and conditions that a distance exists as a substrata, either through the approach or distance in which magnitude will never know how close far or you are to the other. When solidarity comes down to simply saying "I am with you", it does not translate to sympathy for the other, nor does it seek closeness to it, reducing itself to expressing itself through tolerance. The adhesion to the other, as a standard to shorten distances, is the product of the recognition of an isolated, fractioned and meaningless world, giving to the fellow samples of fraternity.

For Dussel, solidarity goes beyond tolerance and fraternity, it is a face-to-face meeting of Levinas, where the neighbor, represented by the "good Samaritan" of the biblical parable, will be thrown out of the way; that is, the neighbor is the subject located outside the totality of the system, in the exteriority, will be the other with which proximity is established in the subject-subject relationship establishing the experience of subjectivity-tosubjectivity, identifying from the spheres of respective worldviews [22].

Solidarity with the transmigrant is not passive tolerance, defined as indifference to the suffering of the other. Passive tolerance means not taking responsibility, hospitality and caring for others; which is out of the way and excluded from the whole world of life [21]. The solidarity that arises from the encounter with the transmigrant is a constitutive solidarity of the being-in-the-world that comes from the otherness, the recognition of oneself and the plurality of the other; where the horizon of meaning is delimited by friendship, love, care and hospitality. It is a praxical solidarity that contributes to the configuration of an ethical reality when experiencing the world of life as an ethos recognizing itself and the other in its desire to be and exist and involves freedom and responsibility towards the other [46].

Solidarity is seen as an element that structures a way of being of man towards his neighbor, a way of understanding-in-the-world and that is shown in the scope of migration processes in the existence of the "houses of the migrant" who has appropriated the responsibility of assisting the transmigrant, offering him shelter, food, rest. According to INM as indicated by $\mathrm{CNDH}$, "Specifically, the migratory stations lack the necessary capacity to shelter in dignified conditions the insured, since they do not have specific areas that allow the separation of men, women, minors, families, psychiatric and infectious contagious patients; similarly, these facilities do not maintain the optimum state of service for which they are intended and do not observe conditions of hygiene, maintenance, ventilation, lighting and recreation areas or outdoors; likewise, the food service is not provided with due opportunity, quality and sufficiency" [26].

The report overlooks the human rights violations and physical, psychological or verbal aggression carried out by the INM staff in these migratory detention centers, denounced as a practice by the Citizen Observatory of Human Rights of Migrants in the year of 2013 [28].

To listen to the sufferer from his life context through the praxis of service allows to deepen the understanding of the structures that victimize him, through the reconstruction of dichotomies of the type: us/them, differentiation/identity, visibility/invisibility, reaffirmation/denial, we are/are different, we are/are not different, inclusion/exclusion. Dichotomies that are established from the our experience in cultural elements, which are derived from the common origin, but which differ from the social interactions that establish the transmigrants through symbolic representations, give meaning to the world of life in which they develop building solidarity [39].

\section{CONCLUSION}

The interpretation of the results obtained from the context of liberation ethics made it possible to identify three periods of growth that show the numerical predominance of the migratory flow from Guatemala, but the growth observed from 2012 is determined by the migrants from 
Honduras and El Salvador. The sociodemographic profile of undocumented migrants is characterized by being a male, who can read and write and worked in their place of origin. It emphasizes the increase of the population that speaks some indigenous language.

The humanitarian crisis affecting migrants in Mexico is determined by extortion and attack, mainly affecting migrants from Honduras. In considering the transmigrant as an ethical subject of victimization, the humanitarian crisis shows the need to promote praxical solidarity based on friendship, love, care and hospitality.

The analysis of the ethical foundations of migratory movements in the southern border of Mexico shows that praxical solidarity represents a hermeneutic nucleus in the historical praxis of exclusion, marginalization and segregation of the migrant, so that praxical solidarity offers the possibility of human life that reveals the care of oneself and the other, linked to the desire to be and exist to be realized as a possibility that is in the real world of life.

On the other hand, it opens the horizon to carry out studies oriented to explore the corporate responsibility of the socially involved institutions in the attention to the migrants in both sides of the southern border of Mexico. It is important to highlight the participation of "local and central governments" as fundamental partners to address the socio-demographic factors that are propitiating migratory movements in Central America.

\section{COMPETING INTERESTS}

Authors have declared that no competing interests exist.

\section{REFERENCES}

1. Inter-American Commission on Human Rights. Human rights of migrants and other persons in the context of human mobility in Mexico. Washington, D.C.: Inter-American Commission on Human Rights; 2013.

2. Cruz EH. Through mexican eyes: Mexican perspectives on transmigration. Val $U \mathrm{~L} R$. 2012;46(4):1019-1052.

3. Correa-Cabrera G. Seguridad y migración en las fronteras de México: Diagnóstico y recomendaciones de política y cooperación regional. Migración y Desarrollo. 2014;12(22):147-171. Spanish.

4. Casillas R. Los migrantes indocumentados: su vulnerabilidad y la nuestra. En: Armijo-Canto $\mathrm{N}$, editor. Migración y seguridad: nuevo desafío para México. México: Colectivo de Análisis de la Seguridad con Democracia (CASADE); 2011.

5. Fábregas-Puig A, González-Ponciano R. The Mexico-Guatemala, MexicoGuatemala border: 1983-2013. Frontera Norte. 2014;26(Número especial 3):7-35. Spanish.

6. Ruiz-Marrujo O. Los riesgos de cruzar. La migración centroamericana en la frontera México-Guatemala. Frontera Norte. 2011; 13(25):7-41. Spanish.

7. Amnesty International. Invisible victims. Migrants on the move in Mexico. London: Amnesty International Publications; 2010.

8. Basail-Rodríguez A. Las fronteras como metáforas de riesgo. Antropológicas. 2009; 11:35-49.

9. Bello-Reguera G. Emigración e ilegalización: Una mirada ética. Dilemata. 2012;4(8):83-97.

10. Haselsberg B. Decoding borders. Appreciating border impacts on space and people. Planing Theory \& Practice. 2014; 15(4):505-526.

DOI: $10.1080 / 14649357.2014 .963652$

11. González RG. Learning to be illegal: Undocumented youth and shifting legal contexts in the transition to adulthood. American Sociological Review. 2011;76(4): 602-619.

DOI: $10.1177 / 0003122411411901$

12. Ousey GC, Kubrin $\mathrm{CH}$. Exploring the connection between immigration and violent crime rates in U. S. Cities, 19802000. Social Problems. 2009;56(3):447473.

DOI: 10.1525/sp.2009.56.3.447

13. Campos-Delgado AE. La línea... "está ahí, es algo que se ve, pero que también se siente": Imaginarios de frontera de las juventudes "al sur". Revista Limina R. Estudios Sociales y Humanísticos. 2010; 8(2):46-70. Spanish.

14. Basail-Rodríguez A. El riesgo como dispositivo de política simbólica. Sobre las inseguridades imaginadas entre fronteras y desastres naturales. Anuario del Centro de Estudios Superiores de México y Centroamérica. 2012;17:258-285. Spanish. 
15. Small ML. How to conduct a mixed methods study: recent trends in a rapidly growing literature. Annu Rev Sociol. 2011;37:57-86.

DOI: 10.1146/annurev.soc.012809.102657

16. Bowen GA. Document analysis as a qualitative research method. Qualitative Research Journal. 2009;9(2):27-40.

DOI: 10.3316/QRJ0902027

17. Ololube NP, Kpolovie PJ. Approaches to conducting scientific research in education, arts and the social sciences. Online Journal of Education Research. 2012; 1(3):44-56.

Available:http://www.onlineresearchjournal s.org/lJER

(Accessed 10 March 2016)

18. Pollock JL. Technical methods in philosophy. Colorado: Westview Press; 1990.

19. Dussel E. Ethics of Liberation: In the age of globalization and exclusion. London: Ducke University Press; 2013.

20. Dussel E. La ética de la liberación: Ante el desafío de Apel, Taylor y Vattimo con respuesta crítica inédita de K.-O. Apel. Toluca, Méx.: Universidad Autónoma del Estado de México; 1998. Spanish.

21. Dussel E. Deconstruction of the concept of "tolerance": from intolerance to solidarity. Constellations. 2004;11(2):326-333.

DOI: 10.1111/j.1351-0487.2004.00380.x

22. Dussel E. From fraternity to solidarity: Toward a politics of liberation. Journal of Social Philosophy. 2007;38(1):73-92.

DOI: 10.1111/j.1467-9833.2007.00367.x

23. Fereday J, Muir-Cochrane E. Demonstrating rigor using thematic analysis: A hybrid approach of inductive and deductive coding and theme development. International Journal of Qualitative Methods. 2006;5(1):80-92.

DOI: $10.1177 / 160940690600500107$

24. Instituto Nacional de Migración. Estadísticas migratorias. México: Secretaría de Gobernación. Serie estadística del periodo 2002 a 2014. Spanish.

Available:http://www.politicamigratoria.gob. mx/es mx/SEGOB/Boletines Estadisticos (Accessed 10 July 2016)

25. Encuesta de Migración de la Frontera Sur. Encuesta de migración de la frontera sur. México: Coedición del Colegio de la Frontera Norte. Serie estadística del periodo 2004-2014. Spanish.
Available:http://www.colef.mx/emif/publica cionessur.php

(Accessed 10 July 2016).

26. Comisión Nacional de los Derechos Humanos. Informe especial de la Comisión Nacional de los Derechos Humanos sobre la situación de los derechos humanos en las estaciones migratorias y lugares habilitados del Instituto Nacional de Migración en la República Mexicana. México: Comisión Nacional de los Derechos Humanos; 2005. Spanish.

27. Comisión Nacional de los Derechos Humanos. Informe especial sobre el secuestro de migrantes en México. México: Comisión Nacional de los Derechos Humanos; 2011. Spanish.

28. Ávila A. Informe sobre estaciones migratorias en Iztapalapa, Puebla y Saltillo del Instituto Nacional de Migración. México: Instituto para la Seguridad y la Democracia; 2013. Spanish.

29. Castles S, Miller MJ. La era de la migración. Movimientos internacionales de población en el mundo moderno. México: Cámara de Diputados; 2004. Spanish.

30. International Organization of Migration. World migration report 2013. Migrant well-being and development. France: International Organization of Migration; 2013.

31. United Nations Development Programme. Human Development Report for Latin America 2013-2014. Citizen security with a human face: Evidence and proposals for Latin America. Panama: United Nations Development Programme; 2013.

32. Elo S, Kyngäs $H$. The qualitative content analysis process. J Adv Nurs. 2008;62(1): 107-115.

DOI: 10.1111/j.1365-2648.2007.04569.x

33. Rodríguez-Sabiote C, Lorenzo-Quiles O, Herrera-Torres L. Teoría y práctica del análisis de datos cualitativos. Proceso general y criterios de calidad. Revista Internacional de Ciencias Sociales y Humanidades, SOCIOTAM. 2005;15(2): 133-154. Spanish.

34. Gioia DA, Corley KG, Hamilton AL. Seeking qualitative rigor in inductive research: Notes on the Gioia methodology. Organizational Research Methods. 2012; 16(1):15-31.

DOI: $10.1177 / 1094428112452151$

35. Tracy SJ. Qualitative quality: Eight "bigtent" criteria for excellent qualitative 
research. Quality Inquiry. 2010;16(10):837851.

DOI: $10.1177 / 1077800410383121$

36. Martínez-Velasco G. Inmigrantes laborales y flujo en tránsito en la frontera sur de México: Dos manifestaciones del proceso y una política migratoria. Revista Mexicana de Ciencias Políticas y Sociales. 2014;59(220):261294. Spanish.

37. Casillas R. Construcción del dato oficial y realidad institucional: Disminución del flujo indocumentado en los registros del INM. Migración y Desarrollo. 2012;10(19):33-60. Spanish.

38. Kearney M. La doble misión de las fronteras como clasificadoras y como filtros de valor. En: Velasco Ortiz L, editor. Migración, fronteras e identidades étnicas transnacionales. México: El Colegio de la Frontera Norte; 2008. Spanish.

39. Kauffer-Michel EF. De la frontera política a las fronteras étnicas. Refugiados guatemaltecos en México. Frontera Norte. 2005;17(34):7-36. Spanish.

40. Garduño E. Antropología de la frontera, la migración y los procesos trasnacionales.
Frontera Norte. 2003;15(30):65-90. Spanish.

41. Ariza M. Itinerario de los estudios de género y migración en México. En: Ariza M, Portes A, editores. El país trasnacional. Migración mexicana y cambio social a través de la frontera. México: Universidad Nacional Autónoma de México; 2007. Spanish.

42. Jaspers K. Philosophy. Chicago: The University of Chicago Press. 1970;2.

43. Burgos E. Me llamo Rigoberta Menchú y así me nació la conciencia. México: Siglo Veintiuno Editores; 2007. Spanish.

44. Rosset $P$, Martínez-Torres ME, Hernández-Navarro L. Zapatismo in the movement of movements. Development. 2005;48(2):35-41.

45. Galemba RB. Remapping the border: Taxation, territory and state power at the Mexico-Guatemala border. Journal of Environment and Planning D: Society and Space. 2012;30(5):822-841.

46. Rillo AG, Vega-Mondragón L, Duarte-Mote J. Responsabilidad médica: Entre la libertad y la solidaridad con el paciente. Med Int Mex. 2013;29(3):311-317.

(c) 2017 Rillo and Martínez-Carrillo; This is an Open Access article distributed under the terms of the Creative Commons Attribution License (http://creativecommons.org/licenses/by/4.0), which permits unrestricted use, distribution, and reproduction in any medium, provided the original work is properly cited.

Peer-review history:

The peer review history for this paper can be accessed here: http://sciencedomain.org/review-history/19521 